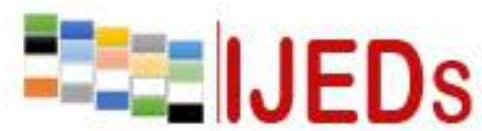

http://ijeds.ppj.unp.ac.id/index.php/IJEDS

\title{
DEVELOPMENT OF READING COMPREHENSION TEACHING MATERIALS USING THE CIRC MODEL IN PRIMARY SCHOOL
}

\author{
*Jumaini, Nurhizrah Gistituati and Darnis Arief \\ Graduate Program of Elementary Education, FIP Universitas Negeri Padang, Indonesia \\ Email : anijumaini226@gmail.com
}

*Corresponding Author, Received: November 12, 2018, Revised: December 10, 2018, Accepted: December 21, 2018

\begin{abstract}
Motivated by teaching materials that are used by teachers which do not contain the complete reading process (pre-reading, reading, and post-reading). This study aims to develop reading comprehension teaching materials using the CIRC model for elementary school class $\mathrm{V}$ that is valid, practical, and effective. This type of research is development research. This study uses the ADDIE model which consists of 5 stages, namely: the stage of analysis, design, development, and implementation, and evaluation. Validity test data is obtained through assessment sheets of teacher and student responses. Effectiveness is seen from the activities of students, assessment of the process and results of the test of reading comprehension of students. Based on the results of the validity, practicality, and effectiveness tests obtained teaching materials that are valid, practical, and effective, and able to improve reading comprehension skills. It can be concluded that teaching reading comprehension materials using the CIRC model developed can be used in reading comprehension learning in grade $\mathrm{V}$ of Elementary School.
\end{abstract}

Keywords: CIRC, Reading Comprehension, Teaching Materials

\section{INTRODUCTION}

Reading has a very important role in efforts to develop the intelligence of students, without having reading skills, students will have difficulty in understanding any learning. Many studies on reading skills such as in Malaysia (Javed, Lin SiewEng, Abdul, Mohamed, Semry, and Maniam 2015), Singapore (Gonzales, 2016), Fhilipina (Patrisha, 2016), Indonesia (Bambang, 2014), Iran ( Hamidavi, Mansoureh, Gorjian, 2016), Turkey (Gurses, 2016), Australia (Bouvet, 2016). Japan (Khaki, 2014) and China (Jiang, 2015) which states that reading skills are important not only in Indonesian 


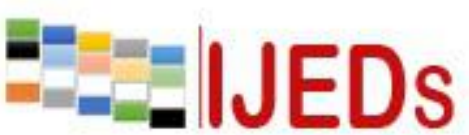

http://ijeds.ppj.unp.ac.id/index.php/IJEDS

language learning, but also in other learning. This is because all learning basically emphasizes the effort to understand a reading. The process of reading learning is not the only purpose of reading learning, but by doing the right process will affect the acquisition of results and understanding after reading.

The reading process is three stages namely, pre-reading, reading, and post-reading, as expressed by Stone (2013) there are 3 stages in reading, namely: (1) pre-reading, (2) during-reading, and ( 3) post-reading. The process of learning to read should look in full and thoroughly the type of reading that is done and the right model to use. Reading comprehension is one type of reading activity and must be done with the correct reading technique. There are a number of basic things in reading comprehension, namely effort or motivation to gain meaning, understanding reading comprehension which involves the knowledge and experience of the reader, the process of reading content and the teaching materials that he uses.

All reading learning processes will certainly work properly if accompanied by appropriate teaching materials. A learning cannot be separated from the source of learning, the role of the teacher is very important because the teacher should make the teaching material. Teaching materials used in the learning process are all forms used to assist teachers in carrying out teaching and learning activities. Good and ideal teaching materials are teaching materials that are in accordance with the applicable competencies and in accordance with their needs and characteristics. In the learning process the teacher should prepare himself in presenting teaching materials, determine the activities to be carried out together with students, be able to improve students' reading skills especially in reading comprehension, and as a means of supporting learning so as to achieve the goals to be achieved.

The fact in the field is based on the results of observations and interviews with several class IV teachers at SDN 16 Tuapejat, Sipora Utara Subdistrict. Several problems were encountered in reading comprehension, namely: (2) students are not invited to read the correct technique at the current reading stage. (3) students are not invited to retell the contents of the reading text and conclude at the time of reading. (4) teaching materials do not contain all indicators and do not represent the KD that must be mastered by students. (5) teaching materials used are not in accordance with the 


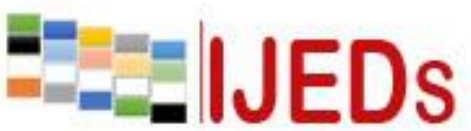

http://ijeds.ppj.unp.ac.id/index.php/IJEDS

characteristics of students. (6) the learning process does not involve students actively and creatively in understanding the contents of the reading. (7) in reading comprehension the teacher has not used the correct reading comprehension technique. It is seen that the presence of students in reading their lips is still tight, and their hands are still pointing with a pen. (8) teacher creativity in designing teaching materials is still lacking.

Based on the results of the analysis of the books and teaching materials above, there are deficiencies found, among others: teaching materials used by the teacher do not contain the complete reading process. In terms of design, teaching materials used tend to be less attractive to students. Teaching materials only use one dominant color, namely: white as a background with little variation on the writing that is colored red, so that this is not in accordance with the characteristics of students in his age who like bright colors and interesting images.

The issue of teaching reading comprehension skills above is also supported by the International Journal of research results from Ness Molly (2011: 4) which explains that some teachers do not understand the stages of the correct reading skills process, even though this is an important basis of reading comprehension. Harvey (2013) explains that students are only focused on reading, but have not been able to understand the contents of the reading. In line with that, Hausheer (2012.) in his research explained (1) students had difficulty in reading, (2) The mode used by the teacher was still inaccurate, so students were less eager to read, (3) the text used was too difficult 4) lack of willingness of students to read.

The shortcomings of teaching materials have an impact on the learning process of reading students such as: (1) students do not predict the contents of the text either from the title of the text or from the media image, (2) students do not know the correct steps in the reading process ) students have difficulty in responding to information from the text that is read, this is seen when students are asked to answer questions based on the text. The above problems can be overcome by teachers by developing reading and teaching materials effectively and creatively by using appropriate reading models that are in accordance with the characteristics of students by developing teaching reading 


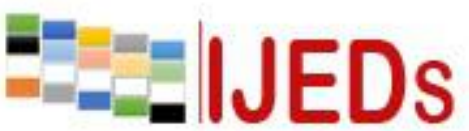

http://ijeds.ppj.unp.ac.id/index.php/IJEDS

\section{International Journal of Educational Dynamics}

Vol. 1 No. 1 (pp. 162-168) December 2018

p_ISSN 2655-4852

e ISSN 2655-5093

comprehension materials using Cooperative Integrated Reading and Composition (CIRC) learning models.

The CIRC model is a model that can help students in reading comprehension, according to (Madhu Gupta and Jyoti Ahuja 2014) CIRC is a comprehensive approach to teaching in reading, composition, and spelling for high school elementary classes. By developing teaching materials that use the CIRC model will be able to improve the learning atmosphere of students more stinging which makes students eager to learn.

\section{METHOD}

This type of research is development research. Development research is research carried out to produce or improve existing products. According to Setyosari (2015) development research is research directed at producing products, designs, and processes. The development model used is the ADDIE model, this model consists of five stages, namely analysis (analyze), design (design), development (development), implementation (implementation), evaluation (evaluation). In the analyze phase, performance analysis, needs analysis and analysis of students is carried out, then the design stage is designing reading skills teaching materials using the CIRC model in elementary school class $\mathrm{V}$, the development stage is the next step in the design phase. to produce valid and practical learning devices. At this stage validity is carried out on the aspects of content, language, and graphics of teaching materials. The instruments used were the validation sheet of teaching material contents, language validation sheets of teaching materials, and graphic material validation sheet. Furthermore, the practicality stage aims to see the level of ease and practicality of the teaching materials developed. The instruments used were the RPP forced observation sheet, teacher response questionnaire sheets, and responses questionnaire sheets of students. Then at the stage of effectiveness is done to find out whether or not the expected goals are maximally achieved through the teaching materials developed. The instruments used were observation sheets of students 'activities on effectiveness, assessment sheets for the process of understanding reading skills, and the results sheets of students' reading comprehension tests. Implementation stage is the stage of application or delivery of instructional materials developed to students and at the same time to see the 


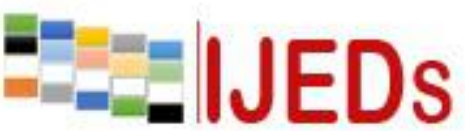

http://ijeds.ppj.unp.ac.id/index.php/IJEDS

effectiveness of the learning devices developed, the aim is to test the effectiveness of the use of these devices on different objects, situations, and conditions. (evaluation) is a process of assigning values to learning devices developed.

\section{RESULTS AND DISCUSSION}

The results of the study on the development of teaching reading comprehension materials using the CIRC model in the V SD class are seen from the level of validity, practicality, and effectiveness.

\section{Validity}

Validation was carried out on reading teaching materials understanding the CIRC model emphasizing content and constructs. Validation of teaching materials is viewed from several aspects, which consist of aspects of content, language, and graphics. Validation in this study was carried out by expert validators in accordance with the field of study, namely content and language validators, and expert academic validators, as well as practitioner validators from elementary school teachers. Validation is said to be complete, if the validator states that it is valid for the teaching material, so that it is ready for trial. The validation results from expert validators showed that teaching reading comprehension materials using the CIRC model obtained a percentage of $92.63 \%$ with very valid criteria. Meanwhile, practitioners' validators obtained a percentage of $93.1 \%$ with very valid criteria. The validity of teaching reading comprehension materials using the CIRC model in class V Elementary School developed in this study is valid in terms of content and construct. This is in accordance with the results of validation from expert validators and validators of education practitioners. This result illustrates that the teaching material developed has been valid and can be used in the learning process.

\section{Practicality}

After the validation process with experts and education practitioners is completed, a trial is carried out to see the practicality of teaching reading comprehension materials. The trial was conducted in 3 meetings, which were observed by 2 observers. Practicalities observed were the level of implementation of the lesson plan, teacher response questionnaire, and questionnaire responses of students to the 


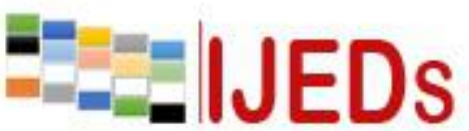

http://ijeds.ppj.unp.ac.id/index.php/IJEDS

practicalities of the learning device. The results of the observations during the trial showed that learning was carried out in accordance with the planning that had been made with the percentage obtained $89.5 \%$ in a very practical category. While the results of the questionnaire from the teacher's response obtained a percentage of $92.5 \%$ with a very practical category, and the results of the questionnaire responses of students obtained a percentage of $90.9 \%$ with a very practical category. This shows that teaching reading comprehension materials using the CIRC model developed very practically are used in the learning reading comprehension process in the fifth grade of elementary school.

\section{Effectiveness}

Teaching materials are said to be effective if they have an effect or a good influence on the achievement of learning objectives. The effectiveness of teaching materials is seen from the activities of students during the learning process and the assessment of the learning process of reading comprehension and the test results of understanding reading comprehension skills of students. Based on the results of data analysis on the activities of students when the learning process obtained a percentage of $91.02 \%$ with a very good category, while the assessment of the learning process of reading comprehension students gained $81.72 \%$ category with very high categories, then the results of reading comprehension skills of students gained a percentage $87.8 \%$ in the very high category. The results of observations of student activities, assessment of processes, and assessment of the results of reading comprehension of students provide a very good picture, meaning that the use of teaching materials in understanding reading learning has been effectively implemented.

\section{CONCLUSION}

Based on the development and trials that have been carried out on reading comprehension teaching materials using the CIRC model in Elementary School class V that the development of reading comprehension teaching materials using the CIRC model from the aspect of validity, shows that this teaching material has very valid criteria, both in terms of content and construct. This is in accordance with the results of validation from expert validators and validators of education practitioners. This result 


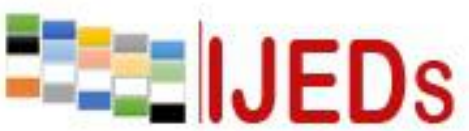

http://ijeds.ppj.unp.ac.id/index.php/IJEDS

illustrates that the teaching material for reading comprehension developed has been valid and can be used in the learning process. Practical results show that teaching materials are very practical, both in terms of wear and implementation. These results are seen from the implementation of the lesson plan, the results of the teacher's response questionnaire, and the results of the questionnaire responses of the students. The effectiveness of learners shows that the development of teaching reading comprehension materials using the CIRC model in the fifth grade of elementary school has been declared effective to improve students' reading comprehension skills. Based on these results, it can be concluded that teaching reading comprehension materials using the CIRC model are declared valid, practical, and effective. Therefore, it is hoped that this teaching material can be used or used as a reference in reading comprehension learning in grade $\mathrm{V}$ of elementary school.

\section{REFERENCES}

Bambang.C.Y. and Widiati, U. 2015. The Teaching of Eflreading in the be Downloaded from the Webpage: Eric doc

Bouvet, E. 2016. Investigating Reading Comprehension and Learning Styles

Gonzales.W.D.W. 2016. Filipino ESL Learners Attitudes Toward Cooperative Learning and Their Relationship to Reading Comprehension. TESOL

Gupta, M. J. A. 2014. Cooperative Integrated Reading Composition (CIRC): Impact on Reading Comprehension Achievement in English among Seventh Graders. IMPACT: International Journal of Research in Humanities, Arts and Literature. Vol. 2, Nomor 5, Mei. International Journal, 11(2), 70-90.

Javed. M., Lin S. Eng and Mohamed. A.R. 2015. Developing Reading Comprehension Modules to Facilitate Reading Comprehension Among Malaysian Secondary School ESL Students. E-ISSN. 1308-1470

Khaki. N. 2014. Improving Reading Comprehension in a Foreign Language: Strategic Reader. Volume 14, Number 2. Relation to Reading Strategies in L2. Volume 28, No. 1 ISSN $1539-0578$ pp. 20- 42

Stone, R. 2013. Best Practices for Teaching Reading. California: Corwin Press.

Zare. P. 2013. The Relationship Between Reading Comprehension and Reading Strategy Use Among Malaysian ESL Learners. Department of Language and Humanities Education Faculty of Educational Studies Universiti Putra Malaysia 43400 Serdang, Selangor, Malaysia. 